\title{
Human health risk assessment of Agent orange/dioxin from contaminated soil in A Luoi district in central Vietnam
}

\author{
Đánh giá rủi ro sức khỏe người dân do đất bị ô nhiễm Chất Da cam/dioxin ở \\ huyện A Lưới miền Trung Việt Nam \\ Research article
}

Le Thi Hai Le*

Faculty of Environmental, Hanoi University for Natural Resource and Environment, 41A Phu Dien street, Bac Tu Liem District, Ha Noi, Vietnam.

During the US - Vietnam War (1961 - 1972), Vietnam was subjected to widespread spraying of the chemical herbicide that is also called Agent Orange containing the most toxic dioxin congener, of 2,3,7,8-Tetrachlorodibenzo( $p$ )dioxin (2,3,7,8-TCDD). A Luoi district belongs to Thua ThienHue province, located in the western part of the North Central coast region of Vietnam. During the Ranch Hand campaign (1965 -1970), A Luoi was heavily sprayed with this herbicide. In order to assess potential human health risks for people due to 2,3,7,8-TCDD exposure from contaminated soil, more than 50 soil samples were collected in A Luoi district area in 2013 and 2014 to determine dioxin concentrations by HRGC/HRMS. Human health risk assessment was applied using internationally recognized approaches. Hazard Quotient (HQ) values, assuming 2,3,7,8-TCDD to be a threshold contaminant, were calculated to be 13.2 and 6.1 ; and Incremental Lifetime Cancer Risk (ILCTR) values, assuming 2,3,7,8-TCDD to be carcinogenic non threshold, were 0.00314 and 0.00627 for adults and children, respectively. These results from exposures in A Luoi show risk values, which are several hundred times higher than acceptable TRVs. The results of this study indicate that, although the war ended nearly 50 years ago, communities living in A Luoi are still at risk of residual dioxin exposure from soils contaminated. Therefore, risk management and mitigation measures are needed, including targeted soil remediation and provision of improved medical and health systems. To our knowledge, this is the first human health risk assessment (HRRA) study in areas sprayed by herbicides during the war in Vietnam.

Trong thòi kỳ chiến tranh giữa Mỹ và Việt Nam (1961 - 1972), Việt Nam phải hứng chịu một luợng lớn chất diệt cỏ còn gọi là chất Da cam, trong đó chúa chất hóa học siêu độc 2,3,7,8Tetrachlorodibenzo (p) dioxin (2,3,7,8-TCDD). Huyện A Luới thuộc tỉnh Thù̃a Thiên-Huế, nằm ở phía tây của vùng duyên hải Bắc Trung Bộ Việt Nam. Trong chiến dịch Ranch Hand (1965-1970), huyện A Luới đã nhiều lần bị phun rải chất diệt cỏ này. Trong 2 năm 2013 và 2014, hơn 50 mẫu đất và thực phẩm đã được thu thập ở khu vực huyện A Luới và phân tích xác định nồng độ dioxin nhằm đánh giá rủi ro về súc khỏe đối với người dân sống trong vùng bị phun rải chất diệt cỏ trong chiến tranh. Nếu giả định chất 2,3,7,8-TCDD là chất độc có nguõng, giá trị HQ (hệ số rủi ro) tính được là 13,2 và 6,1; và nếu giả định 2,3,7,8-TCDD là chất độc gây ung thu không nguỡng, các giá trị ILCR (nguy co ung thu tăng dần suốt đời) tìm được là 0,00314 và 0,00627, tương úng đối với người lón và trẻ em sống ở A Lưới. Khi so sánh với các giá trị TRVs (rủi ro chấp nhận được) cho thấy các giá trị rủi ro ở A Lưới cao hơn vài trăm lần. Tù kết quả này chỉ ra mặc dù chiến tranh đã kết thúc gần 50 năm trước, cộng đồng ở A Luới vẫn có nguy co phơ nhiếm dioxin. Cần thiết phải sóm có các biện pháp quản lý rủi ro và giảm thiểu phơ nhiễm dioxin cho người dân, bao gồm việc xử lý đất và cung cấp các hệ thống bảo vệ môi truờng, y tế và cải thiện sức khỏe. Đây là bài báo đầu tiên về đánh giá rủi ro súc khỏe cộng đồng dân cu do phơi nhiễm dioxin ở nhũng vùng bị phun rải chất diệt cỏ trong chiến tranh.

Keywords: $\quad 2,3,7,8$ TCDD, Agent Orange, A Luoi, dioxin, human health risk 


\section{Introduction}

Dioxins are a general description of a family of 75 similar related compounds commonly referred to as polychlorinated dibenzo dioxin (PCDD) congeners and 135 compounds referred as polychlorinated dibenzo furan (PCDF) congeners. These individual compounds have widely varying harmful effects, some are $10^{5}$ folds as potent as others. This family is divided into eight groups of chemicals, called homologue groups, based on the number of chlorine atoms in the compound. 2,3,7,8-TCDD) is the most toxic of the PCDDs to mammals and has received the most attention. Thus, 2,3,7,8-TCDD serves as a marker for the dioxins (Van den Berg, 2006).

Notable characteristics of dioxins are their environmental persistence and their ability to accumulate within food chains. The lipophilic and hydrophobic properties of dioxin largely determine their distribution in the environment, as well as their fate and distribution in biological organisms, including humans (Van den Berg, 2006).

A Luoi district was selected as study area, since A Luoi was heavily sprayed with herbicides, including Agent Orange containing as a side-product the most toxic dioxin congener, of 2,3,7,8-TCDD (Young Al., 2009). In addition, the former military airbase A Sho was used to store herbicides in A Luoi district. Most residents in A Luoi are from ethnic minorities including Bru, Hoa and Tà Ôi people whose main source of income is from agriculture and handicraft, without industrial activities. According the previous investigation, 2,3,7,8-TCDD is still detected in local soil, sediment, biota and even human blood samples (Hatfield, 2000).

The purpose of this study is to assess recent potential human health risks for people due to dioxin exposure from contaminated soil and food in A Luoi district.

\section{Materials and methods}

Soil, sediment and food samples were collected in 2013 and 2014 in A Luoi district. Chemical analysis of PCDD/Fs was carried out based on method US EPA 1613B using high resolution gas chromatography coupled with high resolution mass spectrometry (HRGC/HRMS), and the $\mathrm{PCDD} / \mathrm{F}$ standard mixtures from Cambridge Isotope Laboratories (CIL, USA) in accordance with US EPA Method 1613B (USEPA, 1994).

This study applied the World Bank POPs Toolkit and other internationally-recognized guidance for performing preliminary quantitative human health risk assessments (Health Canada, 2004; USEPA, 2000, 2008; UNEP, 2005; World Bank, 2008).

Risks were assessed using two distinct approaches:

1) Assumption that $2,3,7,8$-TCDD is a threshold contaminant. This is consistent with current Canadian guidance. Even though dioxins/furans can cause cancer, their toxicity profile suggests that effects are only observed once a specific threshold is reached.
2) Assuming 2,3,7,8-TCDD is a non-threshold contaminant. This is consisting with current US guidance. This approach indicates that there is no set threshold, and that any incremental increase in exposure can result in a greater probability of getting cancer during one's lifetime.

Both approaches require the use of appropriate Toxicity Reference Values (TRV) to characterize the potency of the contaminants of concern and to facilitate calculation of numeric risk estimates.

Using the threshold approach, risk is expressed as a Hazard Quotient (HQ). It is calculated by dividing the calculated total daily dose by a TRV called the Tolerable Daily Intake value, where:

Hazard Quotient $(H Q)=\frac{\text { Calculated Total Daily Dose }}{\text { Tolerable Daily Intake Dose }(T D I)}$

Any concentration resulting in an HQ greater than 0.2 poses a potential risk to human health. A value Total Daily Intake (TDI) of $2.0 \times 10^{-9} \mathrm{mg}$ Toxic equivalent quantity (TEQ) $\mathrm{mg} / \mathrm{kg} /$ day was used for dioxins.

Using the non-threshold approach, risk is expressed as an Incremental Lifetime Cancer Risk (ILCR). It is calculated by assessing ILCR for each exposure pathway independently, and then taking the sum of all exposure pathways. Each ILCR is calculated by multiplying the estimated exposure via that pathway by the cancer slope factor for that pathway where:

$$
\mathrm{ILCR}=\begin{aligned}
& {\left[\begin{array}{l}
\text { tion } \\
\left(\text { Dose }_{\text {Soillngestion }}+\mathrm{SF}_{\text {Oral }}\right]+ \\
\left(\text { Dose }_{\text {WaterIngestion }}+\text { Dose }_{\text {FoodInges- }}\right. \\
\text { tact }
\end{array} \mathrm{SF}_{\text {Dermal }}\right)}
\end{aligned}
$$

Following USEPA (2008), any calculated ILCR greater than $1 \times 10^{-5}$, indicates an unacceptable risk of cancer. It is assumed that exposure to dioxin via contaminated soil can occur a number of ways, including: soil ingestion, food ingestion, dermal absorption and particle inhalation. However, due to the poor solubility of dioxins in water, it has been assumed that this exposure pathway is relatively insignificant, and exposure to dioxins from water sources has not been included in the hazard calculation.

\section{Results and discussion}

\subsection{Problem formulation}

A Luoi district is located in Thua Thien Hue province, on the middle region of Vietnam. From 1965-1970, A Luoi was heavily sprayed herbicides, principally with Agent Orange and to a lesser extent with Agent Blue and Agent White ${ }^{1}$. Nevertheless, there was a US military airbase named A Shau in A Luoi district, which was also used to store herbicides during the war. Most residents in A Luoi are of ethnic minority groups such as the Bru, Hoa and Tà Ôi. They are overwhelmingly self-sufficient farmers; more than $90 \%$ of the land is mixed agricultur$\mathrm{al} /$ residential land areas (i.e. home-stead land). There are no industry activities in A Luoi district (Thua Thien Hue, 
2011).

In A Luoi, a variety of environmental impacts caused by herbicides use were clearly documented by Vietnamese and international researchers (Hatfield 2000, 2011). Elevated concentrations of 2,3,7,8-TCDD were found in soils, sediments and biota in A Luoi, especially inside A Sho airbase (Table 1). High rates of 2,3,7,8 TCDD in total TEQ concentration in samples ranged from $47 \%$ to $99.6 \%$, correlating to those in herbicides sprayed in dioxin hotspots such as Da Nang, Bien Hoa, Phu Cat airbases. In addition, elevated concentration of 2,3,7,8-TCDD were detected in human blood in residents of A Luoi district. Prevailing evidence suggests that dioxin resulted from herbicides sprayed in valley during the war is clearly the primary source in the general environment, the food chain and the human population living of A Luoi district.

Table 1 shows the concentration of 2,3,7,8-TCDD pg/g (ppt) dry weight in soil, sediment, food and biota samples collected in and around A Sho airbase, A Luoi district (Hatfield, 2000, 2011)

\subsection{Hazard identification}

Chemical half-life describes the rate at which a chemical concentration diminishes over time. Dioxins in the human body have half-lives roughly between 7 and 11 years. Paustenbach (1992) reported a half-life of dioxin of approximately $9-12$ years for surficial soils (top $0.1 \mathrm{~cm}$ ), and 25-100 years for deeper soils. In sediments, dioxin can persist for several hundred years (Paustenbach, 1992). In water, an extremely poor solvent for halogenated aromatic compounds, dioxins are mainly attached to suspended particles sorted onto submerged surfaces of aquatic plants.

Table 1. Concentration of 2,3,7,8 -TCDD (pg/g (ppt) dry weight) in soil, sediment, food and biota samples collected in and around $\mathbf{A}$ Sho airbase, in A Luoi district (Hatfield, 2000, 2011)

\begin{tabular}{|c|c|c|c|c|c|}
\hline $\begin{array}{c}\text { Survey } \\
\text { time }\end{array}$ & Sample type & $\begin{array}{c}\text { Sample } \\
\text { size }\end{array}$ & $\begin{array}{c}2,3,7,8-T C D D \\
(\min -\max )\end{array}$ & $\begin{array}{c}\text { TEQ (WHO 2005) } \\
(\min -\max )\end{array}$ & $\begin{array}{c}\% \text { 2,3,7,8-TCDD } \\
\text { of TEQ }\end{array}$ \\
\hline \multirow{4}{*}{1996} & soil, sediment & 3 & $6.9-110$ & $7.8-112$ & $47-97$ \\
\hline & carp & 6 & $1.0-51$ & $1.2-53.7$ & $83-84$ \\
\hline & duck & 2 & ND - 1.4 & $0.2-1.6$ & 87 \\
\hline & manioc & 1 & ND & 0.2 & - \\
\hline \multirow{3}{*}{1997} & soil, sediment & 8 & $1.8-897.8$ & $2-901.2$ & $90-99.6$ \\
\hline & carp & 4 & $7.9-34$ & $8.7-35.4$ & $87-96$ \\
\hline & duck & 1 & 6.1 & 7 & 87.5 \\
\hline \multirow{5}{*}{1998} & soil, sediment & 20 & $4.2-360$ & $4.9-360$ & $85-99$ \\
\hline & carp tissues & 8 & $0.4-21$ & $0.52-22$ & $76-97$ \\
\hline & duck & 2 & $52-82$ & $56-87$ & 75 \\
\hline & chicken & 1 & ND & 0.35 & - \\
\hline & rice & 3 & ND & ND - 0.15 & - \\
\hline $2013-2014$ & soil, sediment & 49 & $1.3-791$ & $1.51-816$ & $87-99$ \\
\hline (This & fish & 3 & $1.34-28.6$ & $1.35-31.8$ & $96-99$ \\
\hline study) & chicken & 1 & 0.02 & 0.33 & 61 \\
\hline
\end{tabular}

In addition, accumulated into aquatic animals such as fish. Fish bioaccumulation factors have been calculated in the range of 37,900-128,000 (USEPA, 2008). At various former airbases studied (i.e., airbases of Da Nang, Bien Hoa, Phu Cat and A Sho) small concentrations of dioxins have been measured in rice, manioc and vegetable samples (Hatfiel, 2000, 2010). Conversely, exceptionally high TCDD levels have been measured in some fish fat, duck and chicken fat samples (Hatfield, 2000, 2010; Schecter et al, 2001).

With respect to toxicology, dioxins were shown to have an exceedingly high toxic potency to mammals. Furthermore, very small exposures of dioxin (TCDD) linked to rare forms of cancer in humans. According to the evaluation of IARC, 2,3,7,8-TCDD belongs to Group 1, the human carcinogenic compounds. Other congeners of PCDDs and PCDFs belong to Group 3, which are unclassified human carcinogens. In the human body, dioxin irreversibility combines with dissolved proteins called the Ah receptor (Ah-R: Aryl or Aromatic hydrocarbon receptor), located in the cytoplasm of human cells (IARC, 1997). The carcinogenicity of $2,3,7,8-\mathrm{TCDD}$ in humans was demonstrated in numerous case-controlled and mortality cohort studies in chemical manufacturing and processing workers, phenoxy herbicide and chlorophenol applicators, Vietnam veterans exposed to Agent Orange, and residents of Seveso, Italy (IARC, 1997). A 2006 study of U.S Army Chemical Corps Vietnam A study (Han et al., 2006) found the statistically significant elevated 2,3,7,8 TCDD levels in blood samples of veterans who reported spraying Agent Orange when compared to veterans who reported they had not sprayed Agent Orange. In March 2008, the Vietnam Ministry of Health declared a list of 17 disease and deformities that were related to exposure to Agent Orange/dioxin. The list by Vietnam MoH contained many of the same diseases identified by US. Department of Veterans Affairs as being related to exposure to dioxin $(\mathrm{MoH}, 2008)$, including diseases of respiratory cancer, prostate cancer, and type 2 diabetes $(\mathrm{MoH}, 2008)$.

\subsection{Exposure assessment}

The purpose of the exposure assessment is to quantify the 
daily exposure of 2,3,7,8 -TCDD from individual specific routes of potential human exposure (inhalation, oral, dermal). Standard exposure rate data have come from studies on accidental, occupational, and residential exposure and from studies on the use of 2,3,7,8-TCDD-contaminated pesticides on agricultural land (USEPA, 2000, 2008; ) for non-carcinogen for local adults and children were calculated (Table 2).

Table 2. Result of Risk characterization (assuming 2,3,7,8-TCDD is a threshold contaminant) for local residents in A Luoi

\begin{tabular}{llll}
$\mathrm{N}^{0}$ & Calculated daily exposures & Adult (mg/kg/day) & Children (mg/kg/day) \\
\hline 1 & Accidental soil ingestion dose & $3.15 \mathrm{E}^{-10}$ & $6.31^{-10}$ \\
2 & Food ingestion dose (for fish and chicken) & $2.1 \mathrm{E}^{-08}$ and $6.80 \mathrm{E}^{-10}$ & $4.26 \mathrm{E}^{-8}$ and $1.42 \mathrm{E}^{-9}$ \\
3 & Inhalation of contaminated particles dose & $4.54 \mathrm{E}^{-13}$ & $1.02 \mathrm{E}^{-12}$ \\
4 & Dermal contact with contaminated soil dose & $4.4 .6 \mathrm{E}^{-9}$ & $8.34 \mathrm{E}^{-12}$ \\
5 & Hazard Quotient (HQ) & $\mathbf{1 3 . 2}$ & $\mathbf{6 . 1 0}$
\end{tabular}

Table 3. Result of Risk characterization (assuming 2,3,7,8-TCDD is a non-threshold contaminant) for local residents in A Luoi

\section{$\mathrm{N}^{0}$ Incremental Lifetime Cancer Risk (ILCR)}

1 Accidental soil ingestion dose

2 Food ingestion dose (for fish and chicken)

3 Inhalation of contaminated particles dose

4 Dermal contact with contaminated soil dose

5 Total ILCR
Adult (mg/kg/day)

$2.68 \mathrm{E}^{-10}$
$6.34 \mathrm{E}^{-08}$ and $6.80 \mathrm{E}^{-10}$
$4.54^{-12}$
$6.66^{-10}$

0.00314

\section{Children (mg/kg/day)}

$5.37 \mathrm{E}^{-10}$
$3.49 \mathrm{E}^{-8}$
$8,43 \mathrm{E}^{-12}$
$6.38^{-10}$

0.00627

Table 4. Concentration of 2,3,7,8 TCDD (pg/g lipid) and TEQ (pg/g) in human blood and breast milk in some communes of A Luoi district [Hafield, 2000]

\begin{tabular}{llccc} 
Location & Sample & $\begin{array}{c}\mathbf{2 , 3 , 7 , 8} \text { TCDD } \\
\text { (pg/g lipid) } \\
\text { Min-Max }\end{array}$ & $\begin{array}{c}\text { TEQ (pg/g }) \\
\text { (WHO 2005) } \\
\text { Min-Max }\end{array}$ & $\begin{array}{c}\text { 2,3,7,8 TCDD } \\
\text { \% of TEQ } \\
\text { Min - Max }\end{array}$ \\
\hline \multirow{2}{*}{ A Sho commune } & Whole blood & $14-41$ & $16.6-45.9$ & $84-89$ \\
\multirow{2}{*}{ Huong Lam commune } & Breast milk & $5.5-16$ & $6.15-21.9$ & $85-96$ \\
\multirow{3}{*}{ Hong Thuong commune } & Blood & ND -17 & $10.0-25.6$ & ND - 66 \\
& Breast milk & $2.9-12$ & $9.33-14.6$ & $27-82$ \\
Hong Van commune & Blood & $7.6-21$ & $11.5-32.3$ & $48-66$ \\
& Breast milk & $7.7-11$ & $9.73-18.5$ & $60-79$ \\
& Blood & ND & $3.53-7.67$ & - \\
& Breast milk & $1.4-5.0$ & $2.99-13.2$ & $37-65$
\end{tabular}

Some studies conducted in the vicinity of former US Army airbases, including Da Nang, Bien Hoa and A Sho have been demonstrated that 2,3,7,8-TCDD contamination spreaded from soils to humans via the food chain (Hadfield, 2000; Schecter et al., 2001; Hun et al., 2006). Recent studies on dioxin exposure from foods in Bien Hoa city demonstrated that local residents had consumed locally raised food such as ducks, chicken, freshwater fish, and other aquatic animals, resulting in very high risk according to daily dioxin intake (Schecter et al., 2001). Possible other modes of ingestion of 2,3,7,8-TCDD include inhalation of dust, skin absorption, and unintentional direct ingestion of soil; in the case of very young children, ingestion may also occur from contaminated objects placed in their mouths. The evidence that foods, human blood and breast milk in A Luoi district were also found to have high dioxin content raising additional concerns related to nutritional and public health issues. These additional "hot spot strata" (i.e., food and humans) are a direct consequence of the mobilization and migration of TCDD from soil through foods (and/or direct contact) into human (Paustenbach et al., 1992).
The goal of the exposure assessment for the human health risk assessment is to determine the total daily exposure (or dose) of 2,3,7,8-TCDD (mg/kg body weight/day). The exposure model typically includes five independent dioxin exposure routes from contaminated areas: soil ingestion, food ingestion, water ingestion, dermal contact, and inhalation of contact particles. Due to the low water solubility of dioxins, the water ingestion route is typically ignored. Using results from published studies of dioxin exposure by humans in vicinity of Bien Hoa airbase (Hanh et al., 2010), we estimated an average body weight for residents of A Luoi District of $50 \mathrm{~kg}$ and $25 \mathrm{~kg}$ for adult and children, respectively. Based on the referenced TDIs of $0.2 \times 10^{-9}$ and other uncertainty factors values recommended by Health Canada (2004), HQs values shown in Tables 2 and 3, HQs were as high as 13.2 and 6.10 for adult and child residents, respectively, or more than a thousand times higher than the 0.2 threshold level. Calculated ILCRs were $314 \times 10^{-5}$ and $627 \times 10^{-5}$ for adult and child residents, respectively, which are higher than the threshold of acceptable risk $\left(1 \times 10^{-5}\right.$, or a lifetime probability of 1 in 100,000). Results indicate that there is a significant human health risk to A Luoi residents due to dioxin exposure. 
Supporting the risk analysis calculations above are documented elevated concentrations of 2,3,7,8-TCDD in blood, tissue and milk of people living at A Luoi (Table 4). There is also documented higher incidences of birth defects and reproductive problems among residents living near Da Nang and Bien Hoa airbases as "dioxin hotspots" (Le et al. 2009; 2010).

It is important to note that the TRVs and uncertainty factors were obtained from data from developed countries; one would expect different factors (perhaps less conservative) for a developing country such as Vietnam.

\section{Conclusion}

This preliminary quantitative risk assessment provides evidence of an increased human health risk for residents living in the A Luoi district as a result of residual 2,3,7,8TCDD from historical use of dioxin-containing herbicides during wartime operations. HQ and ILCR values for adult and children residents of A Luoi district are several hundred times higher than the acceptable TRVs. Results of modelling also indicate that the ingestion of contaminated food, especially aquatic animals (such as fish) account for the greatest potential daily exposure. The results also suggest that the POPs Toolkit can be a useful tool for the assessment of human health risk at sites contaminated with dioxin.

Although the US-Vietnam war has now been over for almost 50 years, the results of this study confirm that the communities in areas sprayed with herbicides are still threatened by dioxin exposure. Therefore, additional risk management/mitigation activities are urgently needed. Risk management/mitigation measures include targeted soil remediation, community education (to prevent and mitigate exposure), and the provision of improved medical and health systems are required.

Acknowledges: The author would like to acknowledge Prof. Olaf Paeker and Dr. Nina Lohmann at the Euro fins GfA Lab Service GmbH, Germany for their help in cross checking of dioxin analysis and Mr. Terry Grim, Environmental Sales Manager at Cambridge Isotope Laboratories for his help in the preparation of this manuscript.

\section{References}

[1] Young, Al. (2009) The history, Use, Disposition and Envionmental Fate of Agent Orange. Springer Verlag. New York, USA.

[2] Van Der Berg M, Birnbaum LS, Denison M, De Vito M, Farland W, Feeley M. (2006) The 2005 WHO revaluation of human and mammalian toxic equivalent factors for dioxin and dioxin - like compounds. Toxicology Sciences 93, 223-241.

[3] Health Canada (2004) Guidance on Human Health Preliminary Quantitative Risk Assessment.
[4] USEPA (1994) Method 1613: Tetra- through OctaChlorinated Dioxins and Furans by Isotope Dilution HRGC/HRMS

[5] USEPA (2000) Exposure and Human health risk Assessment of 2,3,7,8-TCDD and related compounds.

[6] USEPA (2008) Human health risk Assessment based- concentration.

[7] UNEP (2005) Standardized for identification \& qualification of dioxin \& furan releases. Second edition, United Nations Environment Program, Geneva, Switzerland.

[8] World Bank POPs Toolkits (2008) www.popstoolkit.com

[9] Thua Thien Hue Statistical Year Book (2011).

[10] Hatfield Consultants Ltd. and 10-80 Committees (2000) Development of impact mitigation strategies related to the uses of Agent Orange herbicides in the A Luoi Valley, Vietnam. 157p.

[11] International Agency for research on cancer (1997) Reports IARC, USA.

[12] Schecter A., Dai LC., Paepke O., Prange J., Con stable, J.D. Matsuda M (2001) Recent dioxin contamination from Agent Orange in residents of a southern Vietnam city J. Occup. Environ. Med. 43, 435-443.

[13] Paustenbach DJ., Wening RJ., Lau.U., Harington NW., Renix DK, Parson AH (1992) Recent development on the hazards posed by $2,3,7,8$-TCDD in soil. Implication for setting risk based cleanup levels at residential and industrial sites J. Toxicology Environ Health 36, 103-149.

[14] Hatfield Consultants Ltd. and Office 33. Project Reports 2007-2010 (unpublished).

[15] Han KK, Nancy AD, Larry LN, Peter SJL, Katherine Y, Genevieve MM. (2006) Health status of Army Chemical Corps Vietnam veterans who sprayed defoliant in Vietnam. Am. J. Ind. Med. 49(11), 875884.

[16] Decision No. 09/2008/QD-BYT of the Ministry of Health of Vietnam: Promulgating the list of diseases, disabilities, deformities related to exposure to toxic chemicals /dioxin, Hanoi, Vietnam.

[17] Hanh T.T.T, Anh LV, Bich NN, Thomas T. (2010) Environmental health risk assessment of dioxin exposure through foods in dioxin hotspots Bien Hoa city, Vietnam. Int. J. Environ. Res. Publ. Health 7(5), 2395-2406.

[18] Le LTH, Hien LM, Son LK. (2009) J. Organohalogen Comp. 71, 210-215.

[19] Le LTH., Net NX. (2010) Dioxin in Vietnam. J. Organohalogen Comp. 72, 251-254. 